\title{
Three Types of Economic Strategies in Japanese History
}

\author{
Jiayin $\operatorname{Liu}^{1, \mathrm{a}}$ \\ ${ }^{1}$ International College Beijing, Chinese Agricultural University, Beijing, 100027, China.
}

\begin{abstract}
Japanese economy was ruined in the WWII, but grew quickly after this war. The strategies of Japanese government used to recover the economy are analyzed through reviewing the literature in this paper. The conclusions are as follows: after the war, Japanese government had applied various policies to help their economy to grow, although not all of them got the expected result. During 1950-1970, Japanese government carried out trade strategy, which can help Japan increase exports, learn from foreign countries, and improve their industry. From 1980s, Japanese government carried out science and technology strategy, which helped Japanese to create some improved versions of technologies based on knowledge they learned from foreigners before. And during 1985 to 1990, in order to remit the appreciation of yen (Japanese money), Japanese government applied a policy called "quantitative easing policy", which increased the yen in circulation and thus helped yen to depreciate. The first two polices indeed boosted the economy, however the last policy had an negative effect on Japanese economy in the end. But generally speaking, these policies brought Japan to a higher economic level compared with several years before when the WWII ended.
\end{abstract}

\section{INTRODUCTION}

Japan is now a developed country and it has a much higher GDP compared with most countries in the world. Although Japanese economy was destroyed after the WWII, it recovered very quickly after various kinds of policies was applied. China is now a developing country and its economy system is still developing. The objective of this research is to study and analyze Japanese policies in order to help China to boost its economy faster and efficiently. After the WWII (1939-1945), there were various kinds of policies carried out in Japan and these policies have boosted its economy.

During 1950-1970, Japanese government began to carry out the trade strategy. In December 1953, the "Okano Idea" was put forward by the director-general of Japan's economic review hall, Okano, clearly pointed out that the key to the development Japanese economy was to revitalize exports. In December 1955, the "Five-year Plan for Economic Independence" formulated by the Hatoyama Cabinet listed "Revitalizing Trade" as one of the basic policies, and the trade strategy was formed then. From1950 to1953, during the Korean War, as the military and resources base for America according to "Japan-US Security Treaty", Japan gained many benefit from it. During this period of time, Japan produced a huge number of military equipment, goods and materials, which were also called "the special procurement", and offered labors for America. Through these trades, Japan earned a huge amount of money to recover from their economic depression. According to the Japanese official statistics, Japan earned 3.53 billion dollars from these "special procurement" that they provided to the US [7]. But at the same period of time, the embargo towards China and Korea caused loss in Japanese export volume. And during 1953-1970, Japan put its strength mainly on absorbing foreign technologies and skills, and practiced them in their companies, and at the same time, Japanese government tried hard to protect their "infant company", which means new types of companies that had just began to develop their industry.

Then from 1980s, Japanese government carried out the science and technology strategy. In March, 1980, a committee of Japanese government put forward the "guidelines of industrial policy for trade and industry", which clearly put forward the strategy of "building a country by science and technology." Japanese used technologies and skills learned from trades and communication with other countries as a base to improve or create their own technique, and these activities were supported by Japanese government and private enterprise.

During 1985 to 1990 , there was a huge depression took place in Japan, which is known as "bubble economy". The phrase "bubble economy" means that the price in the market goes to a extremely high level for some reason and finally has a big different with the true value of those goods and thus cause the prices to fall rapidly. In the year of 1985, there was a serious appreciation of yen(Japanese money), and in order to remit this appreciation, Japanese government applied the "quantitative easing policy", which was the main force that caused the bubble economy. After this policy carried out, the total amount of yen in circulation quickly increased a lot in a short period of time without being controlled by government on time, then caused the price 
in markets to soaring, which was almost not consistent with the real value of goods itself.

This article analyses the effect of these three major types of strategy above that originally intended to help Japanese economy to grow, mainly by using PPF model.

\section{TRADE STRATEGY}

Because of the limited resources and small land in Japan, for a long period of time, Japan used the way of trading with other countries to attain resources and make a living. Also, Japan is located on pacific volcanic earthquake zone, so it is rich in mineral deposits and is good at industrial production. Thus in exchange, Japanese exported their industrial products to other countries and gained other products from other countries, like fruits or vegetables.

However, although Japan had traded with others for a long time, the trade strategy was not established until the year of 1950, applying to the whole countries. In 1945, Japan surrendered in the WWII, and also ended this war. It was the United State that threw two bombs to Japan and thus force them to surrender. After the attack of those bombs, nearly half of the island was destroyed, and nearly hundred thousand of people were being killed. Thus lots of capitals, sources, labor forces were also diminished, which lead to a poor economic condition at that time.

And after the WWII, from 1950 to 1953, there came the Cold War between Soviet union and America, and then the Korean War began. In order to give supplies to American military during the war, Japan was chosen to be the base or factory for America to attack Korea. According to "Japan-US Security Treaty", Japan totally lost its right to control its own country, and even already became a part of American territory. But actually, this gave Japan a great chance to recover from their poor economy, this was the begin of the economic growth after WWII. During the time, America not only withdrew the punishments for Japan, it also gave Japan directly economic support by giving them money, and some indirectly economic support, which they called it "the special procurement", for example ordered a huge numbers of military equipment, cloth supply, food supply, which were counted as the export of Japan. In Ji's article, he announces that in the year of 1950, special procurement took up about $18.2 \%$ of total Japanese exports, but in 1953 , the number rose up to $63.5 \%$ of total export in Japan [7]. The huge increase of exportation really increased Japanese GDP a lot. Moreover, since Japan was a vanquished country after the WWII, it was controlled by America, and the homeland of Japan also became the territory of US. So many Americans lived in Japan and consumed goods that counts in Japanese GDP. According to the equation of $\mathrm{GDP}, \mathrm{GDP}=\mathrm{C}+\mathrm{I}+\mathrm{G}+\mathrm{EX}-\mathrm{IM}$, both exports and consumer spending increase. As a result, GDP could increase as well. Also, as GDP per capita represents the living standard of people, and Japan indeed recovered from the terrible damage, thus I predict that GDP per capita will also increase a lot

And from 1953 to 1970 , Japan already had a basic GDP level. As the World Bank national accounts data, and OECD National Accounts data files show that Japanese GDP was 212.609 dollars in 1970. And during this period of time, Japan also started to trade more frequently with foreign countries. From these trades, Japan learned a lot of skills and knowledge from others and used them to educate their own people. Thus this increase of knowledge can increase the total number of productions of high-tech products according to the Solow production function, which is $\mathrm{Y}=\mathrm{A} \times \mathrm{F}(\mathrm{K}, \mathrm{L}, \mathrm{NR})$. And if we consider this change in the PPF model, for example, there are two products in the whole society, one is semiconductor, which represents the high-tech productions, and the other is steel, which represents the ordinary industrial products. So if the knowledge level increase, the total production of semiconductor will increase without having any effect on the total production of steels.

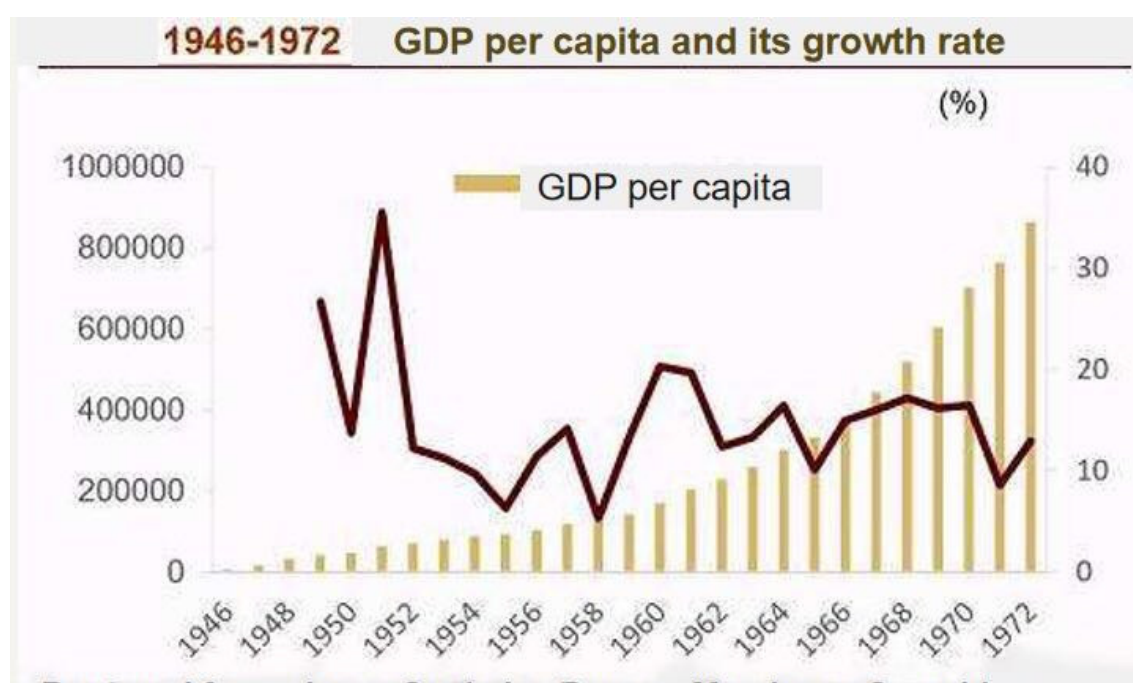

Retrieved from: Japan Statistics Bureau Merchants Securities

Figure 1. 1946-1972 GDP per capita and its growth rate. 


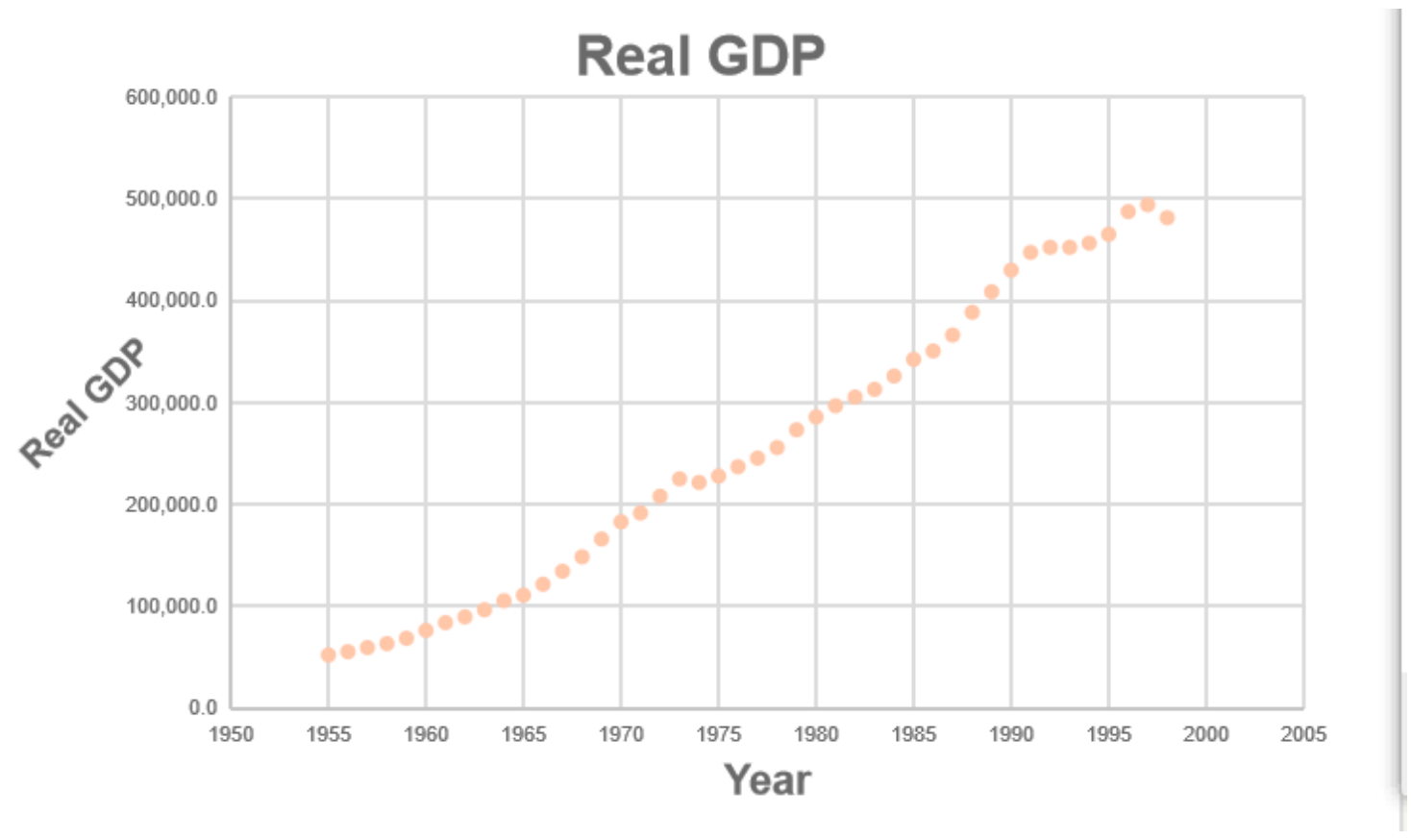

Figure 2. Real GDP.

Muller standard suggests that: industries with little technical experience and low labor productivity, make the product cost higher than the market price, thus cannot compete with foreign companies, but under the protection measures such as tariffs, subsidies, quotas to continue their production after a period of time, and can gain profit and achieve industrial level of other country and then become self-reliance under the condition of free trade [3]. Actually, there were lots of such "infant enterprises" in Japanese society in that time period, which were really easy to be destroyed by the imports produced by some "matured enterprises" from other countries. So in order to.attain a high GDP in Japan, Japanese government protected these factories by increasing the tariff of importations to decrease total number of imports. According to the equation of GDP, the decrease of import can give a higher GDP. Also, this well protection of infant factories gave Japan more possibility to have a big increase of GDP in the futures That is suggested by Lu in the article Japan's Policy of Fostering New Industries and its Enlightenment [4]. He announces that infant industries generally have strong characteristics of the times, which not only conform to the country's development orientation in a specific period, but also play a good leading role in other industries. And during this time, the weal of Japanese also rose, so I predict that GDP per capita will also increase during 1950 and 1970. In figure 1 and figure 2, both the actual GDP and actual GDP per capita increase a lot, which confirms with my prediction.

\section{SCIENCE AND TECHNOLOGY STRATEGY}

In this period of time, began from 1980s, Japan began to use their knowledge gained from trade to create new things. During this period, Japanese government established the science and technology strategy which mainly focused on production of high-tech inventions. Japanese government invested lots of money in digesting and absorbing technologies which were imported from foreigners, and also in inventing new things themselves. For example, in 1985, Japanese government proposed to carry out "international division of labor policy" and "knowledge integration policy"; From the past emphasis on introduction of foreign advanced technology to attaches great importance to the independent development of new technology and new products. And measures were mainly setting up or buying laboratories, running research institutions in some countries of Europe and the United States, and setting high salaries to attract foreign experts to conduct the research and development of science and technology together [4]. The ratio of the cost of importing technologies from abroad to the cost of digesting, absorbing and innovating varies from 1:3 to 1:25, but averages 1:7 [1]. This data shows that Japanese government really payed much more attention to developing and innovating imported technologies compared with the import itself [1]. And according to Xu and Xiao, the annual scientific research expenditure in 1980 and 1990 was 25.4 times and 65.6 times that in 1960 respectively [8]. And if we consider this growth in terms of number, Japan had 303,000 scientific researchers in 1980, 484,000 in 1990 and 558,000 in 1994, which indicates the powerful investment of government in order to carry out the science and technology strategy [9]. Also, Japanese government also supported this strategy from side-on. For example, Japanese government decreased the tax of innovators, and gave money to sciences laboratories, colleges and many enterprises [1], which increased the government spending. Also, many private enterprises invested in scientific inventions, and even more than the government investment. Japanese scientific and technological research expenditure reached a high level of 1.39 trillion 
yen in 1992, accounting for 2.98 percent of the GNP, and private enterprises contributed 11.2 trillion yen, accounting for 80.5 percent of the total [9]. By 1994, there were 641,000 scientific and technical personnel in Japan, of whom 360,000 were owned by enterprises, which were more than the sum of those from universities and national research institutions.[9]. More investments can make more capitals, such as new buildings built into laboratories, and auto machines. According to the Solow production function, if $\mathrm{K}$ increases, other staying still, $\mathrm{Y}$ for high-tech inventions will also also increase. In the PPF model, for example, there are two productions totally in the whole society, high-tech inventions and all other goods, the increase of $\mathrm{K}$ will thus increase $\mathrm{Y}$ of high-tech inventions and no effect on all other goods. Moreover, the improvement of Japanese people also accelerated the strategy progress. Firstly, Japanese pushed forward the spread of propaganda, and strengthened the awareness of people and provided science information to them. Secondly, Japanese government implemented universal education, which could improve the quality and knowledge level of workers, thus would accelerate the speed of technology development. Also, the pressure crated by other countries pushed forward the strategy as well. After Europe and America knew that Japan use technologies which were exploited by them, they began to protect their intellectual property by limiting other countries to use these technologies at a low price. Thus Japan began to develop their original technology exploit [1].

In figure 2, both GDP and GDP per capita increase continuously after 1980s, which is identify with my predictions.

\section{QUANTITATIVE EASING POLICY}

Except for some polices that push the economy to growth, there also exist policies, although not on purpose, that depressed the economy. At around 1985, severe inflation occurred in the US economy. So, the Federal Reserve applied "the tight monetary policy", which led to the sharp appreciation of the dollar. The currency rate between Japan and America is about 1 dollar equals 195 yen in 1978, and then in 1985 rose to 1 dollar equals 258 yen. This appreciation had seriously effect on the export competitiveness, and also caused a huge trade deficit. As the GDP equation indicates that high import and low export will decrease GDP, which was a threat to US's GDP. So America tried to take some action to save its economy, and the signing of the "plaza accord" is the final result of this action. "Plaza accord" is a joint statement issued by finance ministers of the United States, Japan, Britain, Germany and France after a meeting at the plaza hotel in New York on September 22, 1985 [6]. Its main content is: a concerted effort by the five countries to correct the dollar's overvaluation by allowing the major currencies to appreciate against the dollar in an orderly manner [5]. There were two reasons for Japan to sign this accord. Firstly, Japan was threatened by US for US announced to onset the sweeping trade sanctions toward it. Since that time,
Japan was not completely released from America, and most part of Japanese economy was depend on exports to US. For example, in the year of 1982, 1983, and 1984, Japan's trade surpluses were $\$ 6.9$ billion, $\$ 20.53$ billion, and $\$ 33.61$ billion, respectively. And the majority of Japan's trade surplus came from the United States since over the same period, the trade surpluses with the US were $\$ 12.15$ billion, $\$ 18.18$ billion and $\$ 33.08$ billion, respectively [5]. Secondly,

America announced to make yen as the universal money, and let Japan to be the economic giant if Japan signed the accord. America gave Japan both pressure and power, which could easily make Japan to compromise. So finally, Japan, together with UK, France and West Germany, sighed the accord. Then dollar was depreciated by being undersold in the market by those four countries. So conversely, to the dollar, money in each of these countries, including Japan, were appreciated.

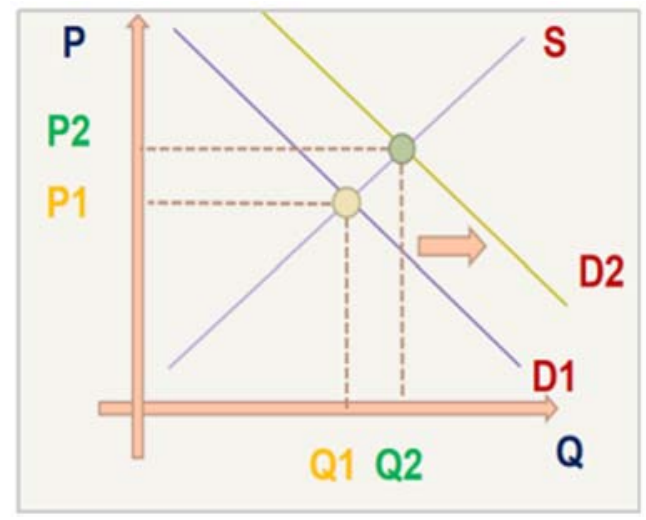

Figure 3. The relationship of demand, supply and price.

If we use producing currency pricing (PCP) method to analyse, this event caused the local currency price of imports to decrease, and caused the local currency price of exports to increase [2]. Thus this event had negative effects on many export businesses in Japan, so in order to comfort these firms, the Japanese central bank printed and issued a huge amount of money, thus increased the money in circulation a lot. According to the demand and supply curve, if there were more money, people's demand would increase, and thus will push the price of goods in the market to a relative high level(figure 3 ), so this boost of price will reflect on goods price, and then, the government will notice it and thus will decrease the price by some ways, for example increase the interest rate. But at that time, Japanese government excessively feared that the appreciation would bring serious depression, so they applied this policy for a pretty long time. Also the government's erroneous judgement toward the economic situation leads to the bad result. So finally, the price in the market continuous to grow and cause a serous inflation, then the government began to realize this serious situation, and began to adjust their policy, lead to the distrust of people, and also because the price of capital could not support its actual value, thus less and less people invested, bought lands or houses, so all these prices decreased expressively, and finally lead to the depression of Japanese economy. 


\section{CONCLUSION}

Japanese economic level is among the top of most countries in the current world, that's because Japanese government has applied appropriate strategies and policies to the situation of the time. The "trade strategy" helped Japan to reestablish their economy after the WWII, and learn new skills from America. And "science and technology strategy" helped Japan develop its own technique which promoted its future development. But some policies gave negative effect on the economy, for example the "quantitative easing policy" gave a shock to Japanese economy which finally leaded to the serious "bubble economy" in Japanese history. As a developing country, China needs to learn from the both the good side and the bad side of Japanese policies and strategies. Firstly, Chinese government needs to encourage and give more supports on importing foreign advance techniques, for example providing duty-free support for the import of technology and equipment from key industries. Or providing special loans and long-term financial support to key industries through development Banks and other financial institutions. Secondly, Japan mainly focuses merely on the development of technique and ignores the basic science development. It is bad to its future development. So learning from this aspect, Chinese government needs to pay attention to the development of basic science, for instance, invest more to the education in specific academic fields, and decrease the tuition of students in the universities. Lastly, although China has been implementing a prudent and slightly loose monetary policy, several cuts in the required reserve ratio and interest rates have caused a large amount of liquidity into the stock market, the real estate market, which should pay high attention to. Therefore, the Chinese government must be cautious about macroeconomic policy regulation, and strictly control market liquidity to avoid the risk of asset bubbles. In addition, economic policy effects need to be weighed and judged comprehensively by considering several economic index and some forecasts about the possible result after the policies are applied.

\section{ACKNOWLEDGMENT}

First and foremost, I would like to show my deepest gratitude to my teachers and professors in my university, who have provided me with valuable guidance in every stage of the writing of this thesis. Further, I would like to thank all my friends and roommates for their encouragement and support. Without all their enlightening instruction and impressive kindness, I could not have completed my thesis.

\section{REFERENCES}

1. J. H. Du \&J. Zhao. The evolution and enlightenment of Japanese science and technology strategy. Development Research. 2007, No. 6, pp. 44-46.

2. M. W. Deng \& J. F. Zhang. Inner relationship between formation of Japan's bubble economy and monetary policy effects-An empirical analysis based on monetary policy transmission mechanism. Studies of Japan. 2017, .31(.3): 27-35.

3. B. Li. On the protection of juvenile industry and the development of juvenile industry. Economic restructuring. 2006, No. 4, pp. 68-70.

4. J. C. Lu. Japan's policy of fostering new industries and its enlightenment. The BBS. 2011, No.18, pp. 96-99

5. D. L. Ren. The influence of plaza accord on Japanese economy and its enlightenment to China, Academic Journal of Shanxi Provincial Committee Party School of C.P.C. 2008, 5(.31): 116-118.

6. H. M. Wang. The causes and bursting of Japan's "bubble economy", Economic fabric. 1998, No.63, pp. 76-77, DOI: 10.15931/j. cnki .1006 $-1096.1998 .02 .022$.

7. P. Ji. Korean war boosting Japanese economy? Literature and History Expo. 2016, No.2, pp:56.

8. S. G. Xu \& X. Y. Xiao. An analysis of Japan's national strategy of science and technology. Japanese Research. 2000, No.3, pp. 16-21.

9. J. Zheng. US-Japan trade and the "plaza accord" more than 30 years ago. China SME. 2019, pp. 65-67. 